\title{
Mobile Banking Services Empowering Youth in Rwanda: A Case of Gisenyi Sector of Rubavu District
}

\author{
Dr. Isaboke Peter Kennedy Nyataya, $\mathrm{PhD}^{1}$, Ukwimanishaka Celine ${ }^{2}$ (Research Student) \\ ${ }^{1}$ Senior Lecturer and Director of Academic Affairs and Quality Assurance, University of Tourism, \\ Technology and Business Studies-Rwanda \\ ${ }^{2}$ University of Tourism, Technology and Business Studies-Rwand
}

\begin{abstract}
The study present study is entitled: "Mobile Banking Services Empowering Youth in Rwanda: A Case of Gisenyi Sector of Rubavu District". The study aimed at assessing how mobile banking services are empowering youth in the selected area for the study. Further, it was not only intended to find out the services offered to the youth pursuing business in the area through the facilitation of mobile banking services but also to analyse challenges faced by youth in business in Gisenyi Sector while making use of mobile banking services. Case study research design was adopted for the study. Data was obtained from both primary and secondary sources which included the use of questionnaire and observation methods, besides, the review of existing and available documents related to the present issue. The target population was 9022 comprising self employed youth in the selected Sector. The representative sample size of the study was 99 respondents consisting of the self employed youth in Gisenyi Sector acquiring mobile banking services and Mtn mobile money, Tigo cash, Airtel money business operators and bank agents selected through the application of convenience sampling and purposive sampling techniques. The obtained data were analysed by use of tables, frequencies and percentages. The study found that youth in Gisenyi Sector, from the mobile banking among the services received included: making money deposits; withdrawing money; money transfers; purchase;account balance checking and bill payment. Further, it was found that mobile banking system has contributed significantly towards the youth business in Gisenyi Sector, for instance, according to the respondents of the study, it has improved the connectivity of business in remote areas; it has connected the youth in business with supplier; it is said to have reduced the risk of theft and frauds in businesses; it has increased the volume of trade per day and, too, it has enhanced working capital among the youth in business. The noted challenges faced by youth in business in Gisenyi Sector included network problems; privacy and security problem; high charges and barrier in withdrawing higher than a specific amount. Hence, the study conclusively states that mobile banking system has played a significant role towards the advancement of the youth in business in Gisenyi Sector. The researchers, therefore, recommend that Rwandan youth should be enabled to continue accessing mobile phones, so that, mobile banking services can be facilitated and hence, serve as alternative way to promote the youth in accessing financial services quickly and easily.
\end{abstract}

Keywords : Mobile Banking Services, Youth, Business, Empowering

\section{INTRODUCTION}

Over the past few years, advancement in information technology has changed the way organisations operate and conduct their business (Al-Jabir, 2012).Technological advancement has brought about the evolution of m-banking and online banking in the banking industry which has revolutionized the manner in which commercial banks and other financial institutions conduct their business. Internet and m-banking has not only made financial organization provide banking services online and via mobile platforms but has also provided customer with easy access to financial services and other benefits.

Mobile banking involves the use of mobile phone for settlement of financial transactions. It supports person to person transfers with immediate availability of funds for the beneficiary. Mobile payments use the card infrastructure for movement of payment instructions as well as secure Short Message Service (SMS) messaging for confirmation of receipt to the beneficiary. Mobile banking is meant for low value transactions where speed of completing the transaction is a key. The services covered under this product include account enquiry, funds transfer, recharge phones, 
changing of passwords and bill payment which are offered by few institution (Anyasi and Otubu, 2009). Mobile banking is the provision or availment of banking services with the help of mobile devices.

In Rwanda, the advent of M-banking was fostered by competition from telecommunication providers such as MTN Mobile Money Services, TIGO Cash Services and Airtel Money Services. The aforementioned services provided, facilitated the youth and other customers to deposit money into their account, transfer money to other users, for instance, sellers of goods and services, relatives and friends. Hence, this made convenient enough for the youth to initiate as well as improve their own businesses.

\section{BACKGROUND TO THE STUDY}

Banking industry has witnessed advancement in technology and the adoption of e-banking service is one of these as it affects banking operations (Adewoye, 2013). With the adoption of Self Service technologies, e-banking system has continued to service the populace, in which mobile banking is one of them. Moreover, the banking industry had to embrace mobile banking in meeting customer demands. Providing banking through mobile has proved fruitful in terms of cost control by employing automated ways of transacting other than the traditional method of labor intensive leading to higher productivity and profitability (Mutua, 2010).

Mobile banking system provides a number of advantages for both banks and customers. First, mobile banking removes geographical limitation to customers and therefore bringing convenience in especially remote and rural areas (Kweyu \& Ngare, 2010). Mobile banking offers millions of people the opportunity of an electronic service to get the access to the management of their account transaction without spending time and money. Second, mobile banking also provides efficient cash management and security of cash. Third, mobile banking can make basic financial services more accessible to business doers by minimizing time and distance to retail bank branches (Adewoye, 2013).

Mobile Banking system is a type of m-commerce service which allows consumers to deliver and receive services through their mobile devices. It provides banking and financial services with the help of mobile telecommunication devices and involves interaction between the consumer and service provider (Donner and Tellez, 2008). Mobile Banking system provides different services, including account balance checks, account transactions (deposits money, withdrawing money and money transfers), mobile airtime purchase, bill payments and credit applications via a mobile device or Personal Digital Assistant (PDA).Positive gains for consumers such as cost effectiveness, personalisation and convenience has contributed to the increased adoption of m-banking over traditional banking methods (Mbiti and Weil, 2011).

Mobile Banking is an innovative application on the mobile phone platform that allows a person to initiate a transaction and make payments by using a mobile phone and its rapid adoption is attributed to high penetration rate of mobile phones in their market. Mobile phones can substitute for travel, allow quicker and easier access to information on prices, enable traders to reach wider markets, boost entrepreneurship and generally makes it easier to do business activities (Wishart, 2006). Mobile phones have become devices for paying merchants, receiving time sensitive information such as stock quotes and aid in critical business processes in many countries (Deans, 2005).

Mobile Banking services offer secure and convenient means for banked and unbanked young people to send and receive money with mobile phones at home and abroad; anywhere at any time (Sadia, 2013).Further, the Mobile Banking is viewed as tool for revolutionising youth business practices, hence, empowering youth business community in one way or another. Several reasons for using mobile banking in businesses have contributed to the state including easier, convenience and more affordable ways of saving, withdrawing, receiving and sending money, balance enquiries, payment of different bills (Must,2010). However, there are several issues including lack of adequate legal framework, security and privacy of mobile transactions which tend to hamper the continued progress of developing this sophisticated mobile banking application.

Mobile banking is used to raise efficiency and boost business growth through cheap, efficient and reliable money service support systems that reduce the need for cash transaction and the risks associated (Higgins et al.,2012). However, before the advent of Mobile banking, young business 
people and others were using paper money which is associated with many problems such as fake currencies, security problems and time saving was very low. Nowadays, through mobile banking, young business people can pay bills, make purchases, transfer money to others and withdraw money using their mobile phones anytime and anywhere and this quickens their business processes. Moreover, young business doers in the remote areas can directly transfer their money to their suppliers without going to the bank (Lawack, 2013). This shows that mobile banking services help young business doers to access usefully large amount of money, which may enable them to get out of poverty and reduce vulnerability through investment in income generating activities or asset creation.

In spite of the growing importance attached to mobile banking system, some young business doers meet some challenges of not knowing how it is used and some of them claimed on services delaying, waiting a long time to access services due to internet problems and certain services are not found through mobile banking system, on the other hand security and trust are other challenges associated with mobile banking use since there is a possibility that the money deposited through mobile banking system may be stolen through hacking of the password (Anyasi \& Otubu, 2009).

\section{Statement of the Problem}

The National Bank of Rwanda's Report (2012), pointed out that the delay in payment of checks between banks, time wasted in banks as people line up in queues waiting for services, errors as result of manual work and fraud related cases were common before the arrival of electronic banking system in the banking industry and this hampered the quick business growth in the country.

Hence, it is against this backdrop that the present researchers decided to undertake the present study with a view to understanding how the youth in Gisenyi Sector of Rubavu District are being empowered in their businesses through mobile banking services provided in the area.

\section{General ObJective of THe Study}

The general objective of the study was to assess how mobile banking system is empowering the youth through their respective businesses in Gisenyi Sector of Rubavu District.

\section{SigNifiCANCE OF THE STUdY}

The fast diffusion of mobile banking is viewed as potential key tool for facilitating financial transactions among youth in business in particular and others in general. Research has shown that youth in business possess mobile telephone and that, the difference between formal and informal businesses is marginal. Though the aforementioned technological facility is accessible to youth across the country, little is known on its impact to the youth in businesses. Hence, there is limited empirical data on the phenomenon. Therefore the present study was intended to fill the current gap of knowledge by exploring the impact of mobile banking system on empowering youth in business.

The findings of the study will enable researchers to get adequate knowledge and understanding how mobile banking system is empowering youth in business in Rubavu District in general and in Gisenyi Sector in particular.

The higher learning institutions such as UTB require that candidates of Bachelor's Degree Programmes must conduct a research study and write a report on the same and, submit it to the university. This will then serve as information resource base and as reference materials for future researchers in terms of the findings of the study conducted.

The findings of this study, if adopted, will be useful to mobile telephone service users in the area for they can improve their services by way of promoting business activities in the area. Besides, those in businesses will be able to strategise on how to realise maximum benefits from mobile banking service providers.

For the policy-makers and agencies such as the National Bank of Rwanda, the findings of the study might be important in informing the policy formulation especially in regards to regulating the mobile banking services in Rwanda. The findings will add dimensions that will help to improve policy direction with regard to regulation of mobile banking as well as factors that can stimulate the economic growth of the country.

\section{CONTRIBUTION OF MOBILE BANKING SERVICE TOWARDS YOUTH IN BUSINESS}

Mobile banking services play a great role in promoting businesses success of young people and other business doers since they improve the connectivity of business in remote areas, they connect the 
business with suppliers, they reduce the risk of theft and frauds in business, they increase the volume of trade per day and they enhance working capital in business operations (Mbogo, 2010).

Mobile banking presents an opportunity for financial institutions to extend banking services to new customers thereby increasing their market. It is a cost effective way to provide banking services to the unbanked business doers because there is no need to set up physical branches to facilitate customers. It is branchless bank model that provides ability to carry out banking transactions via mobile phone (Senso and Venkatakrishnan, 2013) Mobile banking can support a variety of business operations. It has been recognized as a driver of socio-economic development in emerging markets (Nir and Sharad, 2012). In particular, Mobile banking facilitates person-to-person transfer of funds which is very important for emerging economics because it offers financial services to the unbanked people.

According to Ivatury and Mas (2008), mobile banking has also helped to facilitate emergency response and disaster recovery. Mobile phone operators have seen mobile banking as a potential service to offer customers in facilitating them to run their businesses effectively and smoothly and hence increase their loyalty while enjoying quick business operations and affordable fees and messaging charges. Similarly, mobile banking offers a number of banking functions including micropayments to merchants, bill payments to utilities suppliers, person-to-person transfers of funds, and long distance remittances (Donner and Tellez, 2008). Mobile banking improve business operations since it easily allow business doers to run their business in remote areas. Besides these benefits, they further, identified that mobile banking could be beneficial to all in many diverse ways. This is possible if everyone has access to secured saving accounts serviced through technologyenabled retail networks, and connected to the national payment systems including households, government and commercial providers. Vong et al., (2012) identified that micro-entrepreneurs who use mobile banking services in rural areas would benefit positively from the use of it in terms of time, security and convenience.

Moreover, accessibility to mobile finances is considered as key determinant to business success. The speed and safety of mobile banking services has enabled quick and easy transfer of money and this led to business effectiveness. This has boosted the growth of various economic activities, especially in the rural areas, through increased money circulation, local consumption has significantly increased. The reduced costs and increased efficiency and reliability of mobile banking systems have enabled more people to send money to the rural areas and these increased economic activities in those places, for example, it is possible for a farmer to receive money to purchase seeds without unnecessary travel during planting season (Omwansa, 2009).

\section{Challenges Associated With the Use of Mobile Banking Services}

Due to lack of knowledge and awareness about mobile banking, it is a reason for distrust in mobile banking services and it is also another reason for risk and security issue in mobile banking because this is new technology in banking and financial system so all banking customer are not aware about it and feel risk to adopt it, so it is also a big challenge in front of mobile banking services (Vanessa, 2012). The perception of safety may make some people opt out of the service. For privacy and security, the system can be accessed by hackers and this poses a threat about keeping confidentiality of clients' information therefore it is difficult to control who gets access to mobile banking, and what time to access it. The fear of losing money when one loses a mobile phone could lead to fewer subscribers to mobile banking and therefore limit the number that could benefit from the service. Despite these challenges, mobile banking is a potential useful tool in poverty eradication through provision of a secure, inexpensive way to transact (Must \& Ludewig, 2010), well suited for small businesses that might have less access to financial services.

Aker et al., (2011) identified Key challenges in developing a sophisticated mobile banking application. There is lack of common technology standards for mobile banking. Many protocols are being used for mobile banking: Hypertext Mark-up Language (HTML), Wireless Application Protocol (WAP), to name a few. It would be a wise idea for the vendor to develop a mobile banking application that can connect multiple banks. There are a large number of mobile phone devices and it is a big challenge for banks to offer mobile banking solutions on any type of device.

Regulatory Issues such as banking institutions employing telecom agents to manage their mobile banking services. The use of independent telecom agents makes it difficult for the Central bank to 
regulate banking operations to have an universal set of standards. This means that different banks can establish different mobile banking rules, use substandard banking security software and charge high fees for mobile banking which can cause customer to be in confusion (Mbiti \& Weil, 2011). Security of financial transactions, being executed from some remote location and transmission of financial information over the air, is the most complicated challenges that need to be addressed jointly by mobile application developers, wireless network service providers and the banks IT departments (Mbiti and Weil, 2011).

Adewoye (2013), identified that the use of mobile banking is also mitigated by unsecure information where accessing financial services through mobile banking entails submitting personal information through a text messaging platform. Hence, hackers can try to access those messages through unsecure Wi-Fi hot spots. Moreover, some mobile phones are very vulnerable to viruses which provide hackers the opportunity to access banking information through other's mobile phone. In mobile banking there is authentication risk at the login time or when we access our account through the mobile system because in mobile banking for the authentication PINS numbers are used but PINS authentication method is an old method and many security issues such as password theft (Tiwari \& Buse, 2006). Another risk related to authentication in mobile banking as if mobile has stolen then attacker may get the password through the mobile and can access the account by using your password.

Another challenge for the banks is to scale-up the mobile banking infrastructure to handle exponential growth of the customer base. With mobile, the customer may be sitting in any part of the world (true anytime, anywhere banking) and hence banks to ensure that the systems are up and running in a true $24 \times 7$ fashion. As customers will find mobile banking more and more useful, their expectations from the solution will increase. Banks unable to meet the performance and reliability expectations may lose customer confidence. Finally, due to the nature of the connectivity between banks and its customers, it is impracticable to expect customers to regularly visit banks or connect to a website for regular upgrade of their mobile banking application. It will be expected that the mobile application itself check the upgrades and updates and down load necessary patches (Al-Jabir, 2012). However, there could be many issues to implement this approach such as upgrade / synchronization of other dependent components. Moreover, customers will never use mobile financial services if they do not believe that their money will be safe. Fraudulent financial services, although usually on a small scale, do emerge in developing markets from time to time, leading customers to be doubtful about trusting someone else with their money. Furthermore, even if customers have a high degree of trust in the mobile network operator that brands the offering, they will also need to feel comfortable with the local representative of that brand (Mbiti and Weil, 2011).

\subsection{Mobile Banking in Rwanda}

Mobile banking service enables Rwandan to access their bank accounts using their Mobile phones, to access mobile banking services, it is necessary to get subscribed at least one of the local Mobile Phone Operators. The main advantage of the mobile phone lies in its capability to reach everywhere. It transforms the economics of service delivery by reducing the cost of financial transactions and of setting up branches. Mobile banking is also seen as a good way to promote the culture of saving to the millions of rural Rwandans who have a mobile phone but no bank account (NBR Report, 2012).

However, the uptake of mobile banking is still low because of limited understanding of the product, coupled with high levels of financial illiteracy. Another factor is the current structure of the Rwandan economy, which is predominately cash-based. The Uptake of mobile banking still remains low because the economy is still cash-based and not many people accept electronic payments. In Rwandan rural areas, most people have virtually no access to public services and educational opportunities, are malnourished and earn incomes below the poverty line. The mobile banking tool helps such people greatly by providing a way for more efficient money management, which in turn helps those to get out poverty, improve their businesses and provide basic necessities to their families (NBR Report, 2012). Nowadays a growing number of Rwandans, over 90 percent of, have embraced this new technology. The country ranks as the eighth fastest-growing mobile money economies in the world. This is even so witnessed as the number of agents continues to increase as more sophisticated banking services are added to the mobile money platform such as MTN Mobile Money, TIGO Cash and Airtel Money (NBR Report, 2012).

However, these added features will continue to require that the agents have some equipment's and literacy levels to continue support of these functions. With increased uptake of mobile phone services, 
more Rwandans have enrolled into a mobile money service. It can, therefore, be argued that most transactions can be performed using mobile money instead of cash. Mobile money provides a service that allows the sender and receiver to obtain information of each transaction making the service transparent. The consistent performance of this service makes transaction data very reliable and most problems arise from input errors from the customer. This feature results in business streamlining their operations to increase efficiency and boost business growth (NBR Report, 2012).

\subsection{Youth in Employment in Rwanda}

Another major youth employment challenge in Rwanda is the slow job creation and enterprise development required to absorb labor supply. The level and quality of entrepreneurship is low, as evidenced by a relatively small number of businesses. The MSE sector, including formal and informal businesses, comprises $98 \%$ of the businesses in Rwanda and $84 \%$ of all off-farm employment. Most micro and small enterprises employ up to four people, showing that growth in the sector would create significant private sector non-farm employment opportunities (RCA, 2011).

SMEs in Rwanda have remained less competitive compared to regional neighbors. Vital to promotion of job creation and enterprise development is access to finance. Access to financial services is reported as a major bottleneck for enterprise creation and for existing SMEs to expand and grow. As evidenced by PSF survey, financial institutions perceive SMEs as high risk and are therefore inflexible in terms of collateral and repayment terms. This is compounded by the fact that most small borrowers lack experience and understanding of financial organizations and do not have the necessary technical skills to make successful applications (RCA, 2011).

Furthermore, young Rwandans often lack relevant and accurate information about job openings and demanded qualifications or adequately communicate their skills to potential employers. The labor market has not operated as efficiently as possible, and job-seekers have not adequately been able to find job vacancies that exist. There is a key need for government to smooth job search processes through active labor market policy, assisting job seekers to find vacancies through employment Service Centres, Career Advisory Services for students, and collecting viable statistics on employment and labor. There is also a continuous need to analyze the problems of unemployment and underemployment and to equip policy-makers with information and advice on how best to deal with them. In this regard, a functional Labor Market Information System (LMIS) is required (RCA, 2011).

\section{RESEARCH DESIGN}

Case study research design was adopted for the present study.

\subsection{Study Population and Selection of Representative Sample Size}

The total population for the study was composed of 9022 self employed youth in Gisenyi Sector (NISR, 2012).The total representative sample size of the study 99 respondents which covered 40 Mtn mobile money, Tigo cash and Airtel money business operators, banks agents and 59 self employed youth in the mobile banking services in Gisenyi Sector. Slovin's Formula was applied in selecting the representative sample size.

\subsection{Sources of Data and Methods of Data Collection}

Data for the study were obtained from both primary sources as well as secondary sources of data. Primary data for the study was obtained from the selected respondents through the use of questionnaire method and observation method. The secondary sources of data included published and unpublished materials such books, journals, magazines and reports.

\section{Methods of Data Collection}

Data for the study was obtained through the use of questionnaire method and observation as well.

A questionnaire was designed and pre-tested before the researcher administered to the selected respondents for the study. It comprised both close-ended and open ended questions.

The researchers made several visits to the respondents' place of work with a view to observing and understanding how serviced are rendered to mobile banking customers. This, to a large extent, enrichened the researchers overall understanding of mobile banking system is empowering the youth in Gisenyi Sector. 


\section{SumMary OF THE MAJOR Findings OF THE STUDY}

The study established that $97.9 \%$ of the respondents deposit their money through the use of mobile banking system whereas $98.9 \%$ use it in withdrawing money from their accounts, $95.9 \%$ of them use it as way of transferring money, $73.7 \%$ of them said that they use it as a way of airtime purchase to recharge their cell phone, 54.5\% indicated that they use it to check their account balances while 95.9 use in paying bills. In addition, $97.9 \%$ of the respondents stated that mobile banking system is easily available. To other respondents, (83.8\%), the system is cost saving. Further, $87.8 \%$ of the respondents identified that mobile banking is easy to use. It also ensures security of money as reported by $77.8 \%$ of them. Too, mobile banking services are timely available as pointed out by $91.9 \%$ of the respondents. The majority of the respondents $(78.8 \%)$, mentioned that mobile banking services are cheap compared to other electronic banking services rendered to the people in the area.

It was found out that mobile banking system has improved the connectivity of business in remote areas as highlighted by $88.9 \%$ of the respondents. It has connected the young business doers with its suppliers as indicated by $76.8 \%$ of the respondents. The risk of theft and frauds in business has been reduced as identified by $95.9 \%$ of them while it has also increased the volume of trade per day as reported by $69.7 \%$ of them. It has, too, enhanced working capital of young business doers as identified by $64.6 \%$ of the respondents. Therefore, based on the above findings, the specific objective two, to the best knowledge of the researcher has been achieved.

The researchers observed that network connectivity problem was the most challenge faced by young business doers in Gisenyi Sector while using mobile banking system as pointed out by $72.8 \%$ of the respondents; $59.6 \%$ stated privacy and security problems; $56.7 \%$ high charges while $71.7 \%$ indicated the barrier in withdrawing higher than a specific amount. Hence, to the present researcher the aforementioned was achieved.

\section{Conclusion}

The general objective of the present study was to assess how mobile banking system is empowering youth in Rubavu District in general and Gisenyi Sector in specific.

Based on the findings of the present study as highlighted above, it can therefore, conclusively be stated that money depositing, withdrawing money, money transfers, airtime purchase, account balance checks, and bills payment are major services offered though mobile banking system to young business doers in Gisenyi Sector. In addition, mobile banking transactions are easily available everywhere, it is cost saving, it is easy to use, it assumes security of money and its services are timely available. Its services are cheap compared to other electronic banking services. Moreover, mobile banking system prays a great role in youth business activities in Gisenyi Sector since it improves the connectivity of business in remote areas, it connects the young business doers with suppliers, it reduces the risk of theft and frauds, it increases the volume of trade per day and it enhances working capital of young business doers.

The researchers found out that the present mobile banking system adopted in the area, faces various challenges some of which are system delays by the mobile money transfer service providers, slow processing of transactions especially during the weekends, high transactions costs, limit on the amount of money that can be withdrawn in a day and fraud. These challenges can be solved through regular maintenance of mobile money transfer systems which will help in managing the systems' capacity and in turn address the problem of transaction delays and improve customer service through speedy support and lower user charges, as pointed out by the

\section{RECOMMENDATIONS}

Based on the findings of the study, the researchers present the following recommendations that can be adopted by any interested party in the present issue and related issues.

- The majority of Rwandan youth now has access to mobile banking system, hence, it can be adopted as alternative way to promote the poor in accessing financial services quickly and easily, hence the policy makers should now see this opportunity for the country and come up with supportive policy to ensure growth of the economy in the financial sector as well as for rural financial development. 
- Security measures should be ensured by the Government of the day, by the private sector and by all with a view to guaranteeing the mobile banking service users and seekers as well their safety and assurance of the same.

- Mobile banking operators should subscribe to reliable internet providers for effective and efficient service delivery in order to satisfy the needs and wants of the seekers of the servicers provided.

- Telecommunication companies and banks should continue with their innovation endeavours in mobile banking system and invest massively in information technology in order to further promote efficient and smooth service delivery via mobile banking systems.

- Multiple services could be added into the mobile banking system for its efficiency.

\section{Suggestions For Future RESEARCHES}

- The study covered only Gisenyi Sector of Rubavu District. Hence, future researchers can research on the impacts on the spillovers of the use of Mobile banking system in the district and its environs.

- Future studies should be conducted to determine the effects of mobile banking on the profitability of businesses in the area covered under the present study.

- Research should be conducted to determine how the present business community is utilising existing financial opportunities offered through by the mobile banking providers in the area.

\section{REFERENCES}

[1] Adewoye, J. O. (2013). Impact of Mobile Banking on Service Delivery in the Nigerian Commercial Banks. International Review of Management and Business Research .

[2] Al-Jabir, I. M. (2012). Mobile banking adoption: application of diffusion of innovation theory. Journal of Electronic Commerce Research, 13(4), 356-489.

[3] Anderson, J. (2010). M-banking in developing markets: competitive and regulatory implications.info, Vol.

[4] Anyasi, F. I., \& Otubu, P. A. (2009). Mobile Phone Technology in Banking System: It's Economic Effect. Research Journal of Information Technology, 1(1): 1-5.

[5] Bowling, A. (2002). Research methods in health: investigating health and health services. 2nd edition. Buckingham: Open University Press.

[6] Cooper, D. R., \& Schindler, P. S. (2001). Business Research Methods, Seventh Edition. New York: McGraw-Hill.

[7] Creswell, J. W., \& Plano-Clark, V. L. (2007). Designing and Conducting Mixed Methods Research. Thousand Oaks, Calif.: SAGE Publications.

[8] Davidson, N. P. (2011). State of Industry: Results from the 2011 Global Mobile Money.

[9] Deans, P. C. (2005). E-Commerce and M-Commerce Technologies. IRM Press.

[10] Donner, J., \& Tellez, C. (2008). Mobile banking and economic development: Linking adoption, impact and use. Asian journal of communication, 318-332.

[11] Geoffrey, K. (2012). Factors Infuencing Mobile Banking In Kenya: A Case of Kenya.

[12] Georgi, F., \& Pinkl, J. (2005). Mobile Banking in Deutschland. In R. Tiwari, \& S. Buse, The Mobile Commerce Prospects: A Strategic Analysis of Opportunities in the Banking Sector. Der zweite Anlauf: McMillan Publishers Ltd.

[13] Kakooza, T. (1996). An introduction to Research Methodology. Kampala: National Adult Education Association.

[14] Kothari, C. (2004). Research Methodology: Methods \& Techniques. 2nd edition. New Delhi, India: New age International Publishers.

[15] Kothari, R. C. (2005). Research Methodology-Methods and Techniques. Third Edition. New Delhi:: Wiley\& Sons Limited.

[16] Kweyu, M., \& Ngare, P. (2010). Factor Analysis of Customers Perception of Mobile Banking Services in Kenya. Journal of Emerging Trends in Economics and Management Sciences, 5(1) , 1-8.

[17] Masamila, B. (2014). State Of Mobile Banking In Tanzania And Security Issues. International Journal of Network Security \& Its Applications (IJNSA), , 6(4), 258-389.

[18] Mbamba, U. (1999). Theoretical Evaluation of successful Informational Systems Technology. Business Management Review , 6 (2),36-56. 
[19] Mbiti, I. N., \& Weil, D. N. (2011). Mobile banking: The impact of M-Pesa in Kenya . National Bureau of Economic Research.

[20] Mbogo, M. (2010). The Impact of Mobile Payments on the Success and Growth of Micro-Business: The Case of M-Pesa in Kenya. The Journal of Language, Technology \& Entrepreneurship in Africa , 2(1): 1998-1279.

[21] Moshi, F. G. (2011). The Role of Financial Institutions on success of Small and Medium Enterprises in Tanzania: Case study of Dal-Es-Salam Region. Dal-Es-Salam: University of Tanzania.

[22] Must, B. L. (2010). Mobile Money: Cell Phone Banking In Developing Countries. . Policy Matters Journal, Spring 2010, 27-33.

[23] Mutua, R. W. (2010). Effects of mobile banking on the financial performance of commercail banks in Kenya. NAIROBI: UNIVERSITY OF NAIROBI.

[24] Nir, K., \& Sharad, A. (2012). Mobile payment in emerging markets. African Journal of Business Management Vol.3(11).

[25] Ntim, A. L., Evans, O., \& Anthony, F. (2014). Accounting practices and control systems of small and medium size entities: A case study of Techiman municipality. Journal of Finance and Accounting , 6(3),30-40.

[26] Omwansa, T. (2009). M-PESA Progress and Prospects. Innovations case discussion. http://www.strathmore.edu/pdf/innov-gsma-omwansa.pdf > accessed 19th Oct. 2012.

[27] Rajnish, \& Stephan. (2007). The Mobile Commerce Prospects: A Strategic Analysis of Opportunities in the Banking Sector. Hamburg University Press.

[28] RCA. (2011). Women and Youth Access to Finance Program.

[29] Sadia, L. (2013). Access to Mobile Banking and its impacts on livelihoods improvement of the users in the selected areas of Bangladesh. Bangladesh: MSthesis: Bangladesh Agricultural University.

[30] Saunders, M., Lewis, P., \& Thornhill, A. (2007). Research Methods for Business Students, 4th ed. Harlow, England.: Pearson Education Ltd.

[31] Sekaran, U. (2005). Research Methods for Business, a Skill Building Approach (4 ed.). London: McGrawn hills Publishers.

[32] Sekaran, U., \& Bougie, R. (2013). Research Methods for Business - A skill Building Approach. 6th ed. United Kingdom: John Wiley \& Son Ltd.

[33] Senso, N. C., \& Venkatakrishnan, V. (2013). Challenges of mobile-phone money transfer services ${ }^{\text {ee }}$ market penetration and expansion in Singida District, Tanzania. International Journal of Research in Management \& Technology (IJRMT) , 3(6), 2249-9563.

[34] Soroor, J. (2005). Implementation of a Secure Internet/Mobile Banking System. Journal of Internet Banking and Commerce, 10(3) .

[35] Tiwari, R., \& Buse, S. (2006). Mobile Banking: The Mobile Commerce Prospects: A Strategic Analysis of Opportunities in the Banking Sector, " Research project, University of Hamburg, Germany.

[36] Vanessa, P. (2012). Security of Mobile Banking and Payments, SANS Institute InfoSec.

[37] Vesalainen, J., \& Pihkala, T. (2000). Youth entrepreneurial identity, intentions and the effect of the pushfactor. International Journal of Entrepreneurship , 3(2), 145-151.

[38] Vong, J., Fang, J., \& Insu, S. (2012). Delivering financial services through mobile phone technology: a pilot study on impact of mobile money service on micro-entrepreneurs in rural areas. International Journal of Information Systems and Change Management , 6(2),177-186.

[39] Wishart, N. (2006). Micro-Payment Systems and Their Application to Mobile Networks. Washington, DC: infoDev / World Bank.

Citation: Dr. Isaboke Peter Kennedy Nyataya \& Ukwimanishaka Celine. " Mobile Banking Services Empowering Youth in Rwanda: A Case of Gisenyi Sector of Rubavu District." International Journal of Research in Sociology and Anthropology (IJRSA), vol 3, no. 4, 2017, pp. 01-09. doi:http://dx.doi.org/10.20431/2454-8677.0304001.

Copyright: (C) 2017 Authors. This is an open-access article distributed under the terms of the Creative Commons Attribution License, which permits unrestricted use, distribution, and reproduction in any medium, provided the original author and source are credited. 